\title{
1. EPIC AND Novel
}

Two Romes have fallen, but a third stands fast; a fourth there cannot be.

Rome, Byzantium, Moscow: through this prophecy the sixteenthcentury monk Philotheus evades an old and still unanswered question does Russia belong in Europe? - by proclaiming a Europe that spiritually belongs to Russia and should look to Moscow as the true and final capital of a renascent Christendom. For the Slavs to westernize has always seemed a compromise of the otherness and unworldliness that set them apart and above. By the logic of Christianity, their very innocence as outsiders can also signify spiritual election. The conversion of Christendom's northern periphery to its center and capital recalls the miracles of the rejected rock as capstone, the carpenter's son as Messiah, the meek inheriting. Something good can come from Nazareth. Indeed, it is to the Nazareths that one must look to find the future, for the old capitals, Rome as well as Jerusalem, fall prey to worldly success. Philotheus suggests how Slavophiles might welcome the prospect of leading Europe rather than joining it.

Yet danger lurks in this proud calling, for the process of redeeming publicans and sinners entails large risks of joining their number. Already by Philotheus's day the West had seen millennia of conquerors, among them the Romans themselves, battling their way to cultural enslavement. Though politically subjected, the Greeks may have prevailed culturally, as Horace already suspected: "Graecia capta ferum victorem cepit et artes / intulit agresti Latio" ("Conquered Greece conquered her fierce victor and brought the arts into rustic Latium," Epistles 2.1.156-57). The statuesque marble Romanness of Rome was framed by sophisticates who spoke Greek among themselves; in the best circles, Russians after 1812 both celebrated and compromised their expulsion of foreign masters by still speaking French as 
they pursued their own increasingly Napoleonic ambitions. The inheriting meek lose their meekness. Basic to the project of constructing the third and final Rome, in Europe but not of it, was the paradox that the wall erected against European influence would have to be built with European bricks. Perhaps the bulwark could become Russian by being grander than any wall yet built.

In the fabrication of this national identity, novelists enjoyed influence rarely seen in Western letters since antiquity, the influence of prophets. Once Napoleon was beaten, writers in Russia sought to forge an independent literature that would not only celebrate the country's new status as a world power but also allow fallen Europe to read its own destiny. For prophets, the wit or sentimentality of the novel, the bourgeois fantasy that sold books in Paris or London, was no fit medium. While the novel in its materialism and privatization portrayed the spiritual fragmentation of the West, Russian writers aimed to take the genre beyond itself by making it something greater, more public, and more primary — in a word, by making it monumental, that is, epic. It is in precisely these terms that Belinsky, the father of Russian criticism, defined the status of the novel: "The epic of our time is the novel." "The Homeric tradition could liberate Russian writers from the confines of the European novel by providing terms to assert the magnitude of their subject, their magnificent calling, and the finality of their inherited spiritual authority. ${ }^{2}$ The epic, to be sure, is as European as the novel but emerged from a Europe as yet uncorrupted by the Enlightenment and by industrialization, the Europe destined to renew itself on Russian

1 "Èpopeya nashego vremeni est' roman," in V. G. Belinskii, "Razdelenie poèzii na rody i vidy," Sobranie sochinenii v trekh tomakh (Moscow, 1948), 2:38.

2 In a curiously Soviet interpretation of Russia's literary authority, the critic L. F. Ershov disputes all claims that modernist literature can in any way embody the epic tradition. Insisting that classical epics reconstitute the moment of unity in a nation's history such as cannot be achieved in bourgeois society, this orthodox Marxist concludes that contemporary Western literature is fundamentally incapable of producing epic novels. "However," Ershov continues, "to any unbiased observer who can recall but three literary works - "Taras Bulba", War and Peace, and The Quiet Don — it is clear that only in Russia have the lessons of universal, primarily Greek and Latin epic art been consistently and organically mastered." L. F. Ershov, "Traditsii M. Sholokhova i roman-èpopeya v slavyanskikh stranakh," Acta Litteraria Academiae Scientiarum Hungaricae 28, nos. 3-4 (1986): 318. 
soil. The novel might become Russian by being grander than anything yet written.

The turning points in the national history -1812 and 1917 - did in fact inspire responses that pointedly surpassed and questioned the inherited terms of the European novel by invoking the tradition of classical epic. Boris Eikhenbaum has observed that in writing War and Peace Tolstoy used the form of Homeric epic to escape the confines of the English family novel, ${ }^{3}$ and we have argued elsewhere that the structure of heroism in the work owes specific and extensive debts to the Iliad and the Odyssey. ${ }^{4}$ Pasternak's much more oblique and melancholy response to the October Revolution in Doctor Zhivago invokes Virgil's troubled celebration of the Roman revolution in the Aeneid. Pasternak in some measure defines his position (and that of his generation) in the shadow of Tolstoy by thus recalling the burdens and achievements of Virgil in the shadow of Homer. He proposes that Moscow has in fact become the Third Rome, not a final and flourishing bastion of Christian orthodoxy but the capital of a totalitarian empire. Just as Rome's empire left the city "a flea market of borrowed gods and conquered peoples," so Soviet culture may be killing Russian. $^{5}$

Tolstoy and Pasternak were writing within an established national literature, and it is not surprising that as they looked back over the decades to turning points like 1812 and 1917 they should suggest that their works be read beside texts like the Iliad and the Aeneid that were also centrally engaged in the forming of national identities. Gogol and Dostoevsky form another strand within the great tradition of the Russian novel, one in which any trace of classicism is unexpected. Both writers address Petersburg life in their earlier short stories, and Dostoevsky's debts to Gogol on this score are well understood. ${ }^{6}$ But as they wrote their masterpieces, Dead Souls and The

3 Boris Eikhenbaum, Tolstoi in the Sixties, trans. Duffield White (Ann Arbor, Mich.: Ardis, 1982), 227. Originally published as Lev Tolstoi, Kniga Vtoraya (Leningrad, 1930).

${ }^{4}$ See Chapter 4 of this volume.

${ }^{5}$ Boris Pasternak, Doctor Zhivago, prose trans. Max Hayward and Manya Harari, poetic trans. Bernard Guerney (New York: Pantheon, 1958; rpt. New York: Bantam, 1985), 43. See Chapter 5 of this volume.

${ }^{6}$ For some stimulating thoughts on Gogol's influence particularly on Dostoevsky's early works, see Donald Fanger, Dostoevsky and Romantic Realism (Cambridge, Mass.; 
Brothers Karamazov, they turned away from the capitals and from national watersheds, and presumably therefore from any shadows of the epic tradition. ${ }^{7}$ Indeed, Dead Souls seems to deflate the high, laureate style by its mock-heroic account of unwonted excitements in the provincial village of $\mathrm{N}-$, midway between somewhere and nowhere. It was in a similar turning aside from epic and playful dismissal of heroism that the novel got its start in modern literatures with Cervantes, Rabelais, Sterne, and Fielding. Yet in these other literatures epic, as inspiration or target for parody, tends to fall from sight after the first generation, while in Russia, as we have seen, it keeps coming back at the crucial points of national history. The concluding question of Dead Souls, "Whither Rus'?" is more serious in its implications than the preceding text has seemed to be in style, and Gogol came to see his narrative as the first canticle of a divine comedy. When Dostoevsky recalls Gogol's project, as in some measure he does in The Brothers Karamazov, he does so not merely to satirize but to continue it. Dostoevsky also came to view his novel as the first part of some Russian divine comedy. The question of "Whither Rus'?" rises beyond the hollow rhetoric of Dmitri's prosecutor to renew the quest for the Russian identity broadly and seriously and, as we shall argue, against the allusive background of Homer and the classical as well as the Christian origins of the European tradition. The Russian novel, unlike the European, did not invoke the epic tradition to set itself playfully apart before turning to other concerns, but rather to begin a dialogue that is most apparent in the most esteemed texts.

Before turning to Gogol and, more briefly, to Dostoevsky's reflections on the tradition that he inherited from Gogol, we shall need to consider the relationship between epics and novels and in particular the question of how novels can locate themselves within a tradition that is often argued to be antithetical to the very nature of the novel.

Harvard University Press, 1965), as well as Fanger's "Influence and Tradition in the Russian Novel," The Russian Novel from Pushkin to Pasternak, ed. John Garrard (New Haven and London: Yale University Press. 1983), 29-50, and in general Priscilla Meyer and Stephen Rudy, eds., Dostoevsky and Gogol (Ann Arbor, Mich.: Ardis, 1979).

${ }^{7}$ The most comprehensive examination of Gogol's indebtedness to the European literary tradition is Anna Yelistratova, Nikolai Gogol and the West European Novel, trans. Christopher English (Moscow: Raduga Publishers, 1984). She discusses no influence earlier than the "epic novel" (Cervantes, Sterne, Fielding, et al.). 


\section{The Double Plot of Epic}

Epic is not only older than the novel but has a much better memory. Debts within the more idiosyncratic and mutable range of the novel conceal themselves easily, but epic has from the first been preoccupied with its own genealogy. How Aeneas will inevitably launch Rome would have intrigued the ancient reader less than whether Virgil would master or be mastered by the incomparable Homer, whom he rivaled and recreated line by line. Hoc opus, hic labor est. Virgil is reputed to have said that it is easier to steal the club of Hercules than to lift one line from Homer (Vita Donati 46). His heroic terms are apposite: Aeneas's risks rank as nothing compared to Virgil's as heir and rival to Homer. The Aeneid bequeathed to the West a powerful foundation myth, but one centered more on the divine Homer, "the poet," as the wellspring of literature than on pallid, pious Aeneas as the father of Rome. Aeneas does finally get free of father Anchises, but Virgil's struggle with Homer continues to the end without even a forecast of victory.

Of Dante, E.M.W. Tillyard notes that it is not the occasional Ulysses or Farinata that makes the heroic impression, "it is rather the vast exercise of will that went to the shaping of the whole poem." Dante proclaims his own - Christian - victory by bringing Virgil right into the fiction with him as a guide, then leaving him behind, lamented and absorbed. The form itself becomes autobiographical in explaining the act of literary derivation that gave it birth. Speaking in the vernacular, it is Roman Virgil himself who christens Italian as a literary language. Where novels have authors, writers of epic also proclaim themselves authored by the tradition, as Dante notes when he greets his ghostly guide as "lo mio maestro e 'l mio autore." What epic uniquely can offer for glory and reproach is the ability to array All That Precedes as a foil for the current dispensation, and to do so with the particular authority of a form that was as itself in Athens, Rome, and Florence. Where the historical novel, a patently modern form, must often accept the anachronism of presenting old wine in new skins, epic offers a tradition as old as the human events described, yet one incomparably quick at recapitulating millennia of culture by the merest gesture. Devices

${ }^{8}$ E. M. W. Tillyard, The Epic Strain in the English Novel (London: Chatto and Windus, 1958), 16. 
like rosy dawns, adjectives suspended to mock epithets (“Stately, plump...”), comparisons of a warrior to a flame or a lion, or the image of a flickering bough draw the knowledgeable reader into an underworld of fallen empires and their unfading literatures.

Fully realized, then, epic may be said to have a double plot: partly about heroes, partly about its own durability as a form. From the advent of literacy to the current day, epics, through their various levels of allusion, as well as through explicit acknowledgment (for example, Joyce's choice of title for Ulysses), have transmitted the fossilized strata of the epochs of literary development that led up to themselves, that is, of artists' picking up the work of other artists - a record that may contain a tale larger than a given work's announced plot. For that plot will concern at most the emergence of a single sense of nationhood or creed, another Rome, while the embedded record of literary genealogy traces the movement of culture from nation to nation, language to language, religion to religion: Iliad to Odyssey to Aeneid to Divine Comedy. This is not a list of separate items in the way that novels are discrete from one another, but the incremental record of a single pilgrimage to an eternally receding shrine: to Ithaca, to Rome, to the City of God, or to a Moscow or Dublin that is and is not all of these places.

Even in summoning the weight of antiquity, this tradition favors newcomers. As Vico formulated, after decadence comes a ricorso, another Homer in another heroic culture. The quest myths that underlie the tradition allow movement forward in time or space to become movement backward, so that the end becomes the beginning, the last stands first, and innocence constitutes authority. For both Aeneas and Moses, the long exodus to a promised but unseen land proves to be a racial homecoming. The newcomers to that land are its true and original lords. Christianity intensifies the paradox of the first and last, and of the child that shall lead them. The road to Gethsemane returns to and repairs the first garden, and the line of David ends where it began, now in an unfallen Adam. Similarly, Virgil could suggest Augustus not merely as the latest Roman strongman but as the renewal of his line, the new Aeneas. These myths of return have implications that make them central to their cultures. In combining the classical and Christian inheritances, the epic tradition enables a culture that perceives itself as somehow new, or that expresses itself in a yet unestablished literary language - as once Virgil's Rome, so later Dante's 
Florence and Gogol's Russia - to claim spiritual authority beyond its years by involving itself in the very origins of this migrating, self-regenerative culture that always flowers best on its latest frontier.

Starting late and in the east, the Russian renaissance followed the Roman pattern not less but more directly than had the former provinces of the Western empire. Just as the Odyssey translation of Livius Andronicus inaugurated Latin as a literary language, so an early reviewer, N. Polevoi, proclaimed Gnedich's Iliad (1801-29) to be "a treasurehouse of language... [that] exposes the richness, power, and resources of our own language." 9 We shall shortly encounter Gogol's comparable claims for Zhukovsky's Odyssey. Accommodating their resistant language to the Greek hexameter signified literary legitimacy for the Russians no less than for the Romans. For most of its history, the Roman West had known Greek, that both of Homer and of the New Testament, only as filtered through Latin. The Cyrillic alphabet puts the Russians in a different and closer tradition. Of the literary inheritance, a grammarian of the sixteenth or seventeenth century remarked that "Greek and Slavonic letters are like a lamb with its mother (for the Slavonic have proceeded from the Greek) - both of them resemble and harmonize with each other." ${ }^{10}$ Lomonosov, for Pushkin the "Peter the Great of Russian literature," was typically heir to that tradition. Educated in the Slavonic-Greek-Latin Academy in Moscow, he translated parts of Homer (as well as of Virgil and Ovid), proclaiming that "I consider the best of all poets to be Homer."11 As Philotheus's progression - Rome, Byzantium, Moscow - indicates, literature, the empire, and the Church all passed through a formative interlude in Italy, but the Byzantine-Muscovite axis had its own unmediated proximity to Athens, as to Jerusalem. Following in Vico's footsteps, German Romanticism and the scholarship that followed on Wood and Wolf located a bardic and folkloric Homer before and outside

9 Quoted in Viktor Afanasev, ed., N. Gnedich, Stikhotvoreniya i poèmy (Moscow, 1984), 7.

10 Manuscript 423, Sankt-Peterburgskaya Dukhovnaya Akademiya, an untitled grammatical thesis published in M. N. Smenkovskii, Brat'ia Likhudy (St. Petersbrug, 1899), ix; the translation is that of Richard Burgi, A History of the Russian Hexameter (Hamden, Conn.: The Shoe String Press, 1954), 11.

${ }^{11}$ Quoted in A. N. Egunov, "Lomonosov - perevodchik Gomera," in Literaturnoe tvorchestvo M. V. Lomonosova (Moscow-Leningrad, 1962), 215. 
of the European tradition, so that Tolstoy in "What Is Art?" could place Homer next to the Bible as the last "good, supreme art" still accessible to the masses. ${ }^{12}$ There are independent strands of epic inheritance from Homer to the Byzantine "Epic Cycle of Digenis Akritas" and from there into the Kievan period of Russian literature (through old-Russian translations).

To give themselves a language and a literature, the Russians did have to free themselves from the dead weight of Byzantine as well as of French influence. As in the West, it was the classical grandparent that was called in to counteract the medieval parent. Homer worship was a sustained fashion in the nineteenth century. Not only did Tolstoy place Homer next to the Bible, but the youthful Dostoevsky likened him to Christ, ${ }^{13}$ just as Gogol had marked the serious turn in his career by revising "Taras Bulba" to be more Homeric than Homer ${ }^{14}$ and in his final published letters treated the Odyssey almost like holy writ in explaining the bases for patriarchal society.

Sunt lacrimae rerum: epic's excellent, if self-involved, memory also punctures the youthful dreams of national uniqueness and unending mission. A third Rome implies a fourth. In fact, it was the now much replaced Rome herself that invented the migrating capital as a propagandistic device through her claim to be the new Troy. Memory is not a natural ally of chauvinism. In succeeding as the Homer of Rome. Virgil also incited generations of pretenders to become the Virgil of Florence, or Protestant England, or Portugal, or Russia; there will be others. By a final irony, it was in some measure the enduring vigor of Virgil's influence that inspired the Romantics to redirect their emulation to Homer. Epic's second plot, its embedded genealogy, brings arguments more powerful than any creed or nationalism or individual career that it briefly serves. The official pieties

12 Leo Tolstoy, "What Is Art?" and "Essays on Art," trans. Aylmer Maude (London: Oxford University Press, 1929),178. See, in general, Chauncey E. Finch, "Tolstoy as a Student of the Classics," Classical Journal 47 (1952): 205-10. The comparison of Homer to the Old Testament and to Christ was a commonplace already in the eighteenth century; see Kirsti Simonsuuri, Homer's Original Genius: Eighteenth-century Notions of the Early Greek Epic (1688-1798) (Cambridge: Cambridge University Press, 1979), 145-52.

${ }^{13}$ Fyodor Dostoevsky, letter to M. M. Dostoevsky, January 1, 1840, in F. M. Dostoevskii, Polnoe sobranie sochinenii v 30 tomakh, vol. 28, pt. 1 (Leningrad: Nauka, 1985), 69.

${ }^{14}$ Carl Proffer, The Simile and Gogol's Dead Souls (The Hague: Mouton, 1967), 166-82. 
about grand results rest uneasily on the tradition's accumulating and ineradicable documentation of fallen empires and vain human wishes. In conjuring up dead glories, the latter-day bard may even find that they are not quite dead enough. No later capital outshines fallen Troy.

In the central tradition that stretches from Homer to Milton, as to Tolstoy, Joyce, and doubtless beyond, it is less literary similarity that links the texts than their memories of one another in a transmission that has moved from song to written poetry to prose and sometimes back again and that, on the crucial topic of heroic engagement, oscillates unendingly between solemnity and mockery. "Memory," noted Walter Benjamin fifty years ago, "is the epic faculty par excellence,"15 alone responsible for producing the transmission through successive generations. To compare epic and novel is not necessarily to differentiate literary kinds but to contrast the novel as a category (unbounded and indeterminate as it may be) with a tradition, the epic, that can easily flow into and out of this corpus as it has others. We might more accurately speak of epic as a cycle than as a genre, that is, as texts associated less by likeness than by a continuing thread of narrative and allusive gestures (for instance, Dante's Virgil-guide, Milton's proemia) that announce each new text as the final chapter of what precedes. There are, to be sure, continuing characteristics: a strong protagonist, breadth of canvas, some sort of divine apparatus. ${ }^{16}$ As has been repeatedly proven, these characteristics are notoriously poor predictors of where the cycle will next turn. Crafty Odysseus is profoundly not where the Iliad was heading, and, detached from the inevitability of hindsight, Aeneas and Dante-pilgrim mark similarly odd jumps. The legions of poets who have rewritten the Aeneid are mostly forgotten; it was much more likely the subversive Ovid's parody of the epic project in fifteen metamorphic books of universal history that enabled Dante and Milton to reconstitute the Virgilian voice. Goethe's abandoned Achilleid captures less of Homer

${ }^{15}$ Walter Benjamin, "The Storyteller," in Illuminations. ed. Hannah Arendt, trans. Harry Zohn (New York: Schocken Books. 1969), 97.

${ }^{16}$ Serviceable surveys of these characteristics can still be found in Cecil M. Bowra, From Virgil to Milton (London: Macmillan and Co., 1945), 1-32; E.M.W. Tillyard, The English Epic and Its Background (New York: Oxford University Press, 1954), 4-13; Thomas M. Greene, The Descent from Heaven (New Haven and London: Yale University Press, 1963), 8-25; and Daniel Madelénat, L'Epopée (Paris: Presses universitaires de France, 1986), $17-78$. 
than does Hermann and Dorothea. Though the tradition advances by such dodges and displacements, in each new chapter the structure of allusion leaves no doubt about where it has been.

The bid for inclusion within this cycle involves claims to literary legitimacy and cultural centrality of most interest to literatures on the periphery. After an initial dialogue with heroic literature (Cervantes, Rabelais, Fielding, Sterne), the European novel ceased to be preoccupied with this inheritance, so that the double plot mostly drops out of sight. Within the English novel, Tillyard's "epic strain," Leavis's "great tradition," and Kermode's notion of "the classic" trace other forms of magnitude and ambition. ${ }^{17}$ Manzoni's treatise on the historical novel charts how in Italy the cumulative weight of the tradition from Virgil to Tasso became too much to bear; after Tasso, "the public wanted to call the writing of such poems to a halt." ${ }^{18}$ Yet again it is on the frontier, in colonial literatures, that the cycle reemerges. Diagnosing the death of epic in Europe, Hegel in his Aesthetics declared that the aspiring writer of epic "will be necessarily restricted to the portrayal of the victory of some future and intensely vital rationality of the American nation over the prison-house of the spirit which for ever pursues its monotonous task of self-adjustment and particularization.." ${ }^{19}$ Other cases in the West parallel the Russian claim to some such election. Attempting the great Irish novel in the conquerors' language, Joyce called in the epic grandparent, Homer, to cut the Englishmen's tradition down to scale, as did Melville in Moby Dick, his "prose Epic on whaling," other than the bourgeois English novel. As telling in its failed ambitions is Joel Barlow's Columbiad (1807), which deployed Homer, Virgil, and Noah Webster's simplified American spellings to break the ties with England.

${ }^{17}$ E. M. W. Tillyard, Epic Strain; F. R. Leavis, The Great Tradition: George Eliot, Henry James, Joseph Conrad (London: Chatto and Windus, 1950); Frank Kermode, The Classic: Literary Images of Permanence and Change (New York: Viking, 1975).

${ }^{18}$ Alessandro Manzoni, On the Historical Novel, trans. Sandra Bermann (Lincoln and London: University of Nebraska Press, 1984), 103. Originally published as Del romanzo storico (Milan, 1845).

${ }^{19}$ G. W. F. Hegel, The Philosophy of Fine Art, trans. F. P. B. Osmaston (London: G. Bell and Sons, 1920), 4:133.

20 William A. Butler, in an unsigned review in the Washington, D.C., National Intelligencer, December 16, 1851, excerpted in Melville: The Critical Heritage, ed. Watson G. Branch (London and Boston: Routledge and Kegan Paul, 1974), 283. 
The "heroic age" itself thrives best at the borders, as we see in the tendency of the last two centuries to transfer the term epic to oral traditions. For a period the invented bard Ossian stood as Homer's truest successor. Even in evolved literatures, bards do well to claim barbarian blood: to Irish eyes, the Celtic inheritance puts Dublin closer to Ithaca than is London and empowers Yeats to dream of Byzantium. As doomed companion, Queequeg makes a better descendent of Patroclus than could anyone who had heard of Patroclus, and it was the still unmastered wildness of Americans themselves that enabled Melville to construct the Iliadic tale of wrath, Ahab's as once Achilles', in conjunction with the biblical quest of Leviathan, now become a white whale. In its origins and evolution, the word epic has far more to do with the questions of formation of tradition that we are raising than with matters of form or style. For the Greeks, epos was an utterance - a word, a speech, a poem. In reference to verse it designated the vast body of poems in dactylic hexameter, not just the Iliad and Odyssey but other heroic poems in long and short forms, as well as hymns, some comic verse (the Margites), and didactic poems (Hesiod). ${ }^{21}$ It is prestige that attaches epos more specifically to Homer, since for the Greeks Homer was simply "the poet," as Shakespeare is to us "the bard."

The use of epic for the center and pinnacle is more basic than whatever texts are promoted to that position at one time or another. The term is closer in use to classic, a perspective or sense of literary topography describing a corpus with a center, than it is to lyric or drama as they refer to original modes of performance, or even to the radically indeterminate category of the novel, a countering perspective where, though various centers and priorities can be argued (classics, a "great tradition"), the term is applied with no sense of such election and is constantly being redefined by what is produced. Unlike other things that might be called genres (or forms, kinds, species, modes), epic tends to be self-limiting - that is, restricted to its successes. The also-rans may still receive the term from their editors but do not come to mind when the "epic tradition" is being discussed. In naming an "American epic," most respondents would find prose (Moby Dick) less of a disqualification than failure (The Columbiad). ${ }^{22}$

\footnotetext{
${ }^{21}$ See, in general, Severin Koster, Antike Epostheorien, Palingenesia, vol. 5 (Wiesbaden: Franz Steiner Verlag, 1970).

${ }^{22}$ That the epic may be written in prose as well as verse is an article of faith already
} 
The other identifying characteristic of epic is that it is long dead, indeed recurrently dead. In our era it is the novel that has killed it, just as in earlier times it was done in by philosophy (so declared Plato, extruding Homer from the Republic), by tragedy (in Aristotle's diagnosis in the Poetics), by confessional literature (so Augustine, turning from Dido in his Confessions), and then by romance (for example, Ariosto - but perhaps this was the same death that epic had died with Apollonius Rhodius almost two millennia before ${ }^{23}$ or in the somewhat later Greek romances). Even in ages when it is not being written or perhaps read with much enthusiasm, epic maintains its preeminence as the victim of choice for the currently dominant literary form. As we shall soon discuss, it is as the victim of the novel that Lukács and Bakhtin present the epic to us. Bakhtin further argues that the novel is literature's ultimate because ultimately indeterminate form, that is, the infinitely flexible genre that precludes the emergence of any new genres.

Before turning to these theorists we might note the signs that epic may survive this latest death better than the novel will outlast its permanent victory. ${ }^{24}$ Long before Eisenstein used Milton's War in Heaven as the shooting script for the battle on the ice in Alexander Nevsky (1938), ${ }^{25}$ film had singled out epic as its predecessor and esteemed victim much more than it had the novel, though in practice it is the act of novel-reading that film-going replaces. For all the novels that are turned into screenplays, "epic" has currency as a mode of cinema in a way that "novelistic" does not.

The various cinematic applications of "epic" provide a telling reflection of the complexity of its literary uses. "Screen epic" is a thriving branch of popular culture that has inherited certain stereotypical qualities of literary

for Cervantes's Canon of Toledo in Don Quixote, pt. 1, chap. 47.

${ }^{23}$ See Charles Rowan Beye, Epic and Romance in the Argonautica of Apollonius, Literary Structures (Carbondale and Edwardsville: University of Southern Illinois Press, 1982).

24 On the current possibilities for epic, including film, see "Forms of Modern Epic" in Paul Merchant, The Epic, The Critical Idiom, vol. 17 (London: Methuen and Company, 1971; rpt. 1979), 71-94, an engaging brief introduction to the whole epic tradition.

25 On Paradise Lost as a textbook for montage and audiovisual relationships, see Sergei M. Eisenstein, The Film Sense, trans. and ed. Jay Leyda (New York: Harcourt, Brace and Company, 1942), 58- 62. 
epic: scale, celebration of nationhood (Birth of a Nation, Napoleon) or creed (Ben-Hur, The Ten Commandments), and evocation of a past so closed and distant that its iconography translates easily into the future of science fiction (Star Wars). ${ }^{26}$ At its best, especially in the tradition that stretches from Griffith to Kurosawa, this archaizing form maintains its currency remarkably well, especially in comparison to the rapid obsolescence of much literary experiment (the theater of the absurd, the nouveau roman).

Working from Brecht's concept of "epic theater," film theory uses the word quite differently to describe a self-conscious cinema unconstrained by those unities of time, place, and action that Aristotelians stipulated for tragedy. Inspired especially by screen clowns like Charlie Chaplin and Buster Keaton, Brecht saw the externality of film, its capacity for discontinuity, plotlessness, and stylization of gesture as a tool against the bourgeois mentality of the novel. ${ }^{27}$ The audiences "alienated" and provoked to ideological reflection by such films, most notably those of Godard, are taken to be at a polar remove from the escapists lulled by the "screen epics." Whereas those costume dramas aspire without embarrassment to the prestige of monumental art, this other and didactic mode of "epic" cinema can instead provide a critique of tradition itself, as in the famous case of Godard's Le Mépris (1963), a film about a filming of the Odyssey by a Brecht-quoting director, "Fritz Lang" (played by Fritz Lang), bullied by a crass, capitalist American producer (Jack Palance).$^{28}$ In his allegory of the "shipwreck of modernity," as Godard called it, "the eye of the camera watching these characters in search of Homer replaces that of the gods watching over Ulysses and his companions."29

${ }^{26}$ A comprehensive survey of the American and European historical dramas in this category can be found in Derek Elley, The Epic Film: Myth and History (London: Routledge and Kegan Paul, 1984).

27 See especially the excerpts from "Der Dreigroschenprozess," sections III (1) and (6) translated in Bertolt Brecht, Brecht on Theater: The Development of an Aesthetic, trans. John Willet (London and New York: Harcourt, Brace and World, 1964; rpt. 1984), 47-51.

${ }^{28}$ See the Analysis of Robert Stam, Reflexivity in Film and Literature from Don Quixote to Jean-Luc Godard. Studies in Cinema, vol. 31 (Ann Arbor, Mich.: UMI Research Press, 1985), 21-22.

29 Jean-Luc Godard, Godard on Godard, trans. Tom Milne, ed. Jean Narboni and Tom Milne (New York and London: Viking, 1972; rpt., New York: Da Capo Press, 1986), 201. Originally published as Jean-Luc Godard par Jean-Luc Godard (Paris: B. Belfond, 1968). 
These are but straws in the wind, though sufficient to warrant caution in diagnosing the death of cultural forms. Epic is still alive enough as a generative principle to be called in by Brecht as an antidote (and successor) to capitalist art forms and to inspire Godard's apotheosis of the camera. Differently understood, it also lives on in the popular imagination to organize production and consumption of a certain kind of commercial film spectacle. Those disparate applications of the term reflect the dialectic of the epic tradition as it has always advanced both by the big canvasses (whether of popular or high art) and by the critiques and dismantlings of them (in other words, as much by mock-epic as by achieved national epics)..$^{30}$ The development of the cinema has replicated the age-old literary quandary about whether "epic" denotes the largest sweep of action and of meaning - the aspiration to totality - or the most retentive mode of artistic self-consciousness. The evolution of serious film has not been toward the anarchic and ahistorical proliferation once expected but toward the assertion of archetypes, the codification of allusion, the induction of its makers into a guild of auteurs celebrating their forebears. Once the streets of Los Angeles or São Paulo or Melbourne can be shot and edited as a recapitulation of the Berlin of the thirties, the Rome of the fifties, or the utopian Los Angeles of the studios, cinema acquires its own double plot: the quick, capacious memory, the latent internationalism that we have associated with epic. A rhetoric of jump cuts, voice-overs, and tracking shots serves this end neither better nor worse than do similes and epithets. Celluloid classicism works increasingly from a pantheon of Eisenstein. Griffith, Lang, Hitchcock. Godard, Truffaut. Yet, as in the literary tradition, such reflexivity does not necessarily disrupt emotional engagement and the suspension of disbelief, but in providing imaginative distance and protective irony can allow heroic fantasies new scope.

Having survived the advent of writing and then of printing, epic as a process of tradition forming and cultural centering is more resilient than

${ }^{30}$ To trace but one recent swing from dismantling to synthesis (and Left to Right), the antinarrative techniques of the French New Wave proved useful in the revival of the American film industry after 1967. The most extravagant and profitable "screen epics" in film history (for example, the Star Wars and Indiana Jones trilogies) employ overt allusiveness, stylization of gesture, and cartoonlike externality that (pace Brecht and Godard) facilitate escapism. On the first decade of this development, see Robert Ray, A Certain Tendency of the Hollywood Cinema, 1930-1980 (Princeton, N.J.: Princeton University Press, 1985), 272ff. 
purely written forms like the novel or short story, though it must survive each transition by a kind of "grandfather clause," a bemused toleration of it as a living anachronism. Current prospects suggest that it is much more likely the novel itself will end in the graveyard of epic's other destroyers than that epic will forego the millennial parasitism whereby it thrives through the nostalgia and condescension of its various replacements until they are themselves replaced. Yet when literary theorists call epic dead, they do so at the invitation of its practitioners, who know how to exploit this nostalgia. For two and a half millennia, epic has been a song sung at its own funeral, always deepening its poignancy with the promise that any revival of it is the last, the very last, that we are to hear. The epic cycle is a book composed entirely of final chapters.

\section{The Death of Epic}

Too big to be overlooked and firmly planted at the cultural center, epics thus elude literary historians by presenting their credentials so duplicitously. From epoch to epoch the form comes unexpectedly alive only to find another consummation and die yet another final death. As such, the epic is a convenient starting point for teleological theorists, from Aristotle to Bakhtin, who need something big, simple, and defunct as a basis of comparison. ${ }^{31}$ It is instructive to review the fate of Aristotle's dictum that tragedy had absorbed and superseded epic, for within a century after he wrote this, tragedy was reabsorbed into the main epic tradition: Medea moved from Euripides' stage to the hexameters of Apollonius Rhodius's Argonautica and then, after being dramatized in the interval by Ennius, lived on in Virgil's Dido. Epic would die another death, this time for doctrinal reasons, when that erstwhile intemperate admirer of Dido, Augustine of Hippo, turned from Virgil and the pagans to scripture and the new form of the confession. Yet the full literary realization of such autobiography, Dante's Divine Comedy, would bring Virgil and epic back from the grave. To be sure, Dante, like Augustine, was still marching past the tribe of Dido, now led by Francesca da Rimini, but Virgil the seducer

31 On Aristotle's use of Homer in the Poetics, see, in particular, Stephen Halliwell, Aristotle's Poetics (Chapel Hill: University of North Carolina Press, 1986), 253-66. 
(for Augustine) had become Virgil the guide, who could be left behind atop Mount Purgatory, not because his form was moribund, but because it was now securely reborn and redeemed.

This second death proved to be only the start of Virgil's modern Nachleben, for he was destined to be conjured time and again by allusion so that he might confess his obsolescence and once more bequeath his authority. As was noted above, such ghosts favor the frontiers and, within such emergent cultures, outcasts. In their various forms of exile and disenfranchisement, Dante, Milton, Joyce, and Pasternak all provide terms to understand what will be our central case, Gogol's removal to Rome. To this may be added a salient American example, where, as with Gogol, sexual identity plays a central role. To establish Nebraska as a literary landscape within the European canon, Willa Cather in My Antonia has the classicist Gaston Cleric and his pupil, Jim Burden, self-consciously reenact the VirgilDante relationship even as they read Virgil's Georgics, which introduced the Italian landscape into the same tradition. In The Professor's House, Tom Outland, like Burden an orphan, reads the Aeneid amid the ruins of Blue Mesa (a version of Mesa Verde) and imagines before him the very towers of Troy. ${ }^{32}$ It is outsiders - Dante in his terrifying valley, Milton in his dark study, Outland on his lonely bluff, and Cather as heir to a European and male guild - who are most apt to see ghosts, as we shall find with Gogol and his dead souls.

For writers continuing the cycle, the "death of epic" is a topos. ${ }^{33}$ When Virgil said early in his career that he would sing no "kings and battles," he may have meant it (Eclogue 6.3-5), since Homeric epic was for his generation unattainable and perhaps undesired. Whatever pressures of political circumstance (Augustus) and ambition intervened, he did go on to write other things, so that his statement now stands in his oeuvre as a prelude to epic. The epic pilgrimage to which Virgil was giving permanent

${ }^{32}$ See, in general, Paul A. Olson, "The Epic and Great Plains Literature: Rølvaag, Cather, and Neihardt,"' Prairie Schooner 55 (1981): 263-85. The scene may also recall Goethe's reading the Odyssey and discovering the Urmensch in Sicily.

${ }^{33}$ One of the earliest traces of this device is found in Thucydides. "We shall need no Homer to sing our praises," proclaims Pericles to the Athenians in his funeral oration (2.51), testifying both to the doomed self-assurance of imperial Athens and, at another level, to Thucydides' own claims as the writer of another great book about another great war (a greater war, he argues, than the Trojan). 
definition thus starts with refusal, then surmounts it. Within the same tradition Dante-pilgrim similarly declines the invitation to join la bella scuola of Homer, Horace, Ovid, and Lucan. They stand with dignity as a closed chapter that we might call "the death of epic." Dante could join them only by foregoing the voyage to Beatrice. Yet he can arrive at Beatrice only with the help of refugees from that scuola, Virgil and Statius, who equally suggest the chapter as not closed or closable. A heresy larger than joining the pagan bards on their own terms would be to conclude that their art, or any art, is not capable of transfiguration.

The nearly obligatory ecphrases that descend from Achilles' shield in Iliad 18 provide a demonstration of how the cycle fails of closure. Entering Carthage in Aeneid 1, Aeneas sees on the temple of Juno reliefs of the Trojan War and, observing the sufferings of himself and his people thus memorialized by Dido, is heartened and seduced. Like the Sirens' song, this account of "kings and battles" can lure the unguarded audience to oblivion. By staying with Dido and marrying that glorious past, Aeneas, like Dante with the bards of Inferno 4, would go no farther. Yet those very bas-reliefs, Virgil's symbol of a defunct and entrapping art, are the literary stuff out of which Dante crafts the redemptive cycle divinely carved on the first ledge of the mountain (Mary, David, and Trajan in Purgatorio). The very rocks have risen. Epic is dead, long live epic.

On the death of literary forms, Alastair Fowler proposes the following rule of thumb: "Pronounce a genre dead if works related to it directly are no longer widely read, so that its forms have become unintelligible without scholarly effort." ${ }^{34}$ On this score, Homeric epic remains more alive for the modern reader than many of its successors, like the Greek romances or Menippean satire. Unlike the novel, the epic lives not just because it is written and bought but also because it is taught and incorporated into central belief systems. The contrast of epic and novel misleads because only a three-way comparison - novel, epic, and scripture - begins to lead to clarity. To note that the novel comes from the Christian era as the epic does from the pagan nearly reverses their actual literary life in the nineteenth century. For the novel, especially in Russian eyes, was a secular and Western form, while the epic, even Homer and Virgil by posthumous conversion,

\footnotetext{
${ }^{34}$ Alastair Fowler, "The Life and Death of Literary Forms," in New Directions in Literary History, ed. Ralph Cohen (Baltimore: The Johns Hopkins University Press, 1974), 87.
} 
had a status in Christian letters and ecclesiastical education older than Russia itself. ${ }^{35}$ The prospect that the epic might be a dead tradition might have been less worrisome than the fact that the novel, for all its current aesthetic possibilities, had been spiritually stillborn. The sense of historical time moving to apocalypse, a place where the European novel could never go, was not outmoded for Gogol, nor is it, for that matter, for Solzhenitsyn. For such pilgrims, the novel is only a way station. To call a novel The First Circle suggests that a form beyond the novel impends.

Since the novel is the later and currently generative form, some theorists, like Lukács ${ }^{36}$ and Bakhtin ${ }^{37}$ have sought to define it by emphasizing its amorphousness, vitality, and open-endedness in contradistinction to the closed chapter that epic supposedly represents. Both assume that once material has flowed down to the novel and to the swamps of postEnlightenment consciousness from the Pierian spring of epic, it never flows back uphill. Both theorists take epic (almost exclusively Homer) and novel as epitomes of their respective ages. ${ }^{38}$ What sets the forms and ages apart is the onset of indeterminacy in spiritual as in political life, in literary form as in language. For Lukács the characteristic of the epic age, and above

35 The Nachleben of Homer and Virgil can be traced throughout the Renaissance by reading their respective entries in the indices to Ernst Robert Curtius, European Literature and the Latin Middle Ages, trans. Willard R. Trask, Bollingen Series 36 (Princeton, N.J.: Princeton University Press, 1953), and R. R. Bolgar, The Classical Heritage and Its Beneficiaries (Cambridge: Cambridge University Press, 1954). On Virgil, see Domenico Comparetti, Vergil in the Middle Ages, trans. E. F. M. Benecke (London and New York, 1895). Simonsuuri summarizes Homer's role in the earlier conturies (Homer's Original Genius, 3-16) before his survey of the eighteenth century.

${ }^{36}$ Georg Lukács, The Theory of the Novel, trans. Anna Bostock (Cambridge, Mass.: MIT Press, 1971). Originally published as Die Theorie des Romans (Berlin: P. Cassirer, 1920). A helpful introduction to these theories is provided by Michel Aucouturier, "The Theory of the Novel in Russia in the 1930s: Lukács and Bakhtin," in The Russian Novel from Pushkin to Pasternak, ed. John Garrard (New Haven and London: Yale University Press, 1983), 227-40.

37 Mikhail M. Bakhtin, "Epic and Novel" and "From the Prehistory of Novelistic Discourse," in his The Dialogic Imagination, ed. Michael Holquist, trans. Caryl Emerson and Michael Holquist (Austin: University of Texas Press, 1981), 3-83.

${ }^{38}$ As a spokesman for his age, Homer is in considerable decline among classicists. Archeologists no longer feel compelled to heed him at all. Already twenty-five years ago Emily Vermeule, in introducing her important Greece in the Bronze Age (Chicago and London: The University of Chicago Press, 1964), wrote, "Homer has been rejected as evidence, with a pang" (p. x). 
all Homer, is "the adequacy of the deeds to the soul's inner demand for greatness, for unfolding, for wholeness.... Being and destiny, adventure and accomplishment, life and essence are then identical concepts." ${ }^{39}$ Yet the stable, fulfilling age thus described is not a heroic age so much as a patriarchal and hierarchical one, whereas the Iliad at least is more insistently antiauthoritarian. Lukács's description fits the well-meaning Hector far more than it does Achilles. Consider the arc of Achilles' journey to "fulfillment": his murderous wrath against Agamemnon is turned against the whole Achaean army, which is saved only when he finally turns it against Hector and himself. What modern readers tend to find compelling in the conclusion is the remarkable scene where Achilles and Priam, momentarily but with profound understanding, step outside destinies that they both regret. Lukács's hazy ideal scarcely surprises, of course, since it was only under some such protective mist that pagan epic could be allowed to enter Christian classrooms.

In fact, the heroes of classical epic, though not necessarily the secondary characters, tend to embody just those characteristics that both theorists see as setting the novel apart from the epic. The "spiritual homelessness," the ruptured linkage of code to feeling that Lukács sees as the death knell of the heroic age is in fact what sets Achilles apart from his peers, ${ }^{40}$ as it does Aeneas and Dante-pilgrim from theirs. Indeed, such spiritual crises may have been the integrating theme that allowed shorter lays to be organized into the larger structures of Homeric epic. The Iliad strings together various duels and days of glory (for Diomedes, Agamemnon, Hector, Patroclus) that enact heroic values straightforwardly enough and would seem to represent the earlier tradition. Yet the larger tale in which these elements are embedded, the wrath and revenge of Achilles, pivots on questioning, rejecting, and in some measure finally ignoring the very code that he supremely embodies. ${ }^{41}$ It is the critique of war that enables the poem to become the great tale of war.

${ }^{39}$ Lukács, Theory of the Novel, 30.

${ }^{40}$ How much alienation we may see in Achilles and how much we should suspect modern biases in doing so remains the slipperiest of Homeric questions. For the state of the controversy, see James M. Redfield, Nature and Culture in the Iliad: The Tragedy of Hector (Chicago and London: The University of Chicago Press, 1975), 3-29.

41 This position is argued concisely by Adam Parry, "The Language of Achilles," 
Similarly, the new scale allows the traditional trickster of folklore not just to overcome witches and ogres along the way, as Odysseus does Circe and the Cyclops, but to rejoin a whole family turned deceivers (Penelope and Telemachus), so that the intricate process of recognizing one another goes beyond the magic tokens and dropped masks of trickster tales to become a complex analysis of epistemology of memory and desire. Odysseus, famous now and battered, finds himself in competition with the image of the beloved king and father who had left home twenty years before. The requisite happy ending, stable and complete, of an "epic age" is attained in Ithaca only when the notion of happiness itself has been permanently destabilized by the new subjectivities discovered in memory, dreams, and deceit in a text that is itself a self-conscious response to the Iliad. ${ }^{42}$ In Homer, the glorious past does, as Lukács observes, maintain its absolute superiority over the present; but it is a glory that instructively dismantles, discredits, and analyzes itself. If the "epic age" is prephilosophical and unreflective, the great epics are its most philosophical and least characteristic part.

Lukács justly observes that between antiquity and the modern era (as epitomized by the epic and the novel) stands a vast increase in literary attention to alienation and spiritual homelessness. He describes thereby one of the attractions of the epic tradition for novelists who want to overcome the indeterminacy of the novel, the anomie of their age, or their own marginality or that of their culture. Epic does - if only in the retrospect that makes it seem fixed, confident, and official - promise focus and structure. Yet when these great works are executed, tendencies emerge for the wrong hero to carry the tale, for the oldest and doctrinally least acceptable stratum of material to seem the freshest and most appealing, often the pagan rather than the Christian. This most traditional of forms may celebrate some new

Transactions and Proceedings of the American Philological Association 87 (1956): 1-7, reprinted in The Language and Background of Homer: Some Recent Studies and Controversies, ed. Geoffrey S. Kirk (Cambridge: Heffer; New York: Barnes and Noble, 1964), 48-54, and in Homer, ed. Harold Bloom, Modern Critical Views (New York: Chelsea House Publishers, 1986), 109-13. For a wider development of this approach, see Cedric H. Whitman, Homer and the Homeric Tradition (Cambridge, Mass.: Harvard University Press, 1958). See, most recently, Stephen A. Nimis, Narrative Semiotics in the Epic Tradition: The Simile (Bloomington and Indianapolis: Indiana University Press, 1987), 63-73.

${ }^{42}$ For the fullest and most recent interpretation of that literary relationship, see Pietro Pucci, Odysseus Polutropos: Intertextual Readings in the Odyssey and the lliad (Ithaca and London: Cornell University Press., 1987). 
dispensation in its overt plot but make quite a different argument in the internationalism and ungovernable self-regeneration of the allusive style, that second plot of epic which does not respect shifts of doctrine or politics or fashion. It was Dante's intention to move his readers beyond his lively, pagan Inferno, as it was Milton's to get them past the antique heroics of Satan. Not all readers stay the course.

In this early work on epic and novel, Lukács is following in the tradition of Goethe, Schiller, and most immediately Hegel by romanticizing Homer's era and reasserting the ancient habit of leading universal history from some golden age. Lukács harbors hopes of revolutionary change in bourgeois culture that will restore such an epoch, and the epic that expresses it. Though such nostalgia has more sources than can here be disentangled, it is clear that for the theorist this lost paradise provides a manageable basis of comparison for the complexities to follow. Moreover, even Romantics and socialists could not quickly cut lose from pagan literature's long cohabitation with scripture and its notion of innocent and fallen ages. Thanks to the curriculum, epic is wedded to the youth of the reader as to the youth of the race, a process that Joyce depicts in Stephen Dedalus's classroom in the second chapter of Ulysses. Lukács was not yet thirty years old when he wrote his celebration of Homer. As Macaulay in 1825 observed of the names in Milton's catalogues:

Like the dwelling-place of our infancy revisited in manhood, like the song of our country heard in a strange land, they produce upon us an effect wholly independent of their intrinsic value. One transports us back to a remote period of history. Another places us among the novel scenes and manners of a distant region. A third evokes all the dear classical recollections of childhood, the schoolroom, the dog-eared Virgil, the holiday, and the prize. ${ }^{43}$

These habits affect writers of epics and the audiences for which they see themselves as writing, even as they affect theorists. Even if there had been no "epic age," the assumption that there was one shapes the tradition and glamorizes epic ambitions, as they mix cultural imperialism and a quest for lost innocence.

43 Thomas Babington Macaulay, Critical and Historical Essays Contributed to the Edinburgh Review (London: Longmans, Green, and Company, 1909), 1:13, quoted by Donal M. Foerster in The Fortunes of Epic Poetry: A Study in English and American Criticism 1750-1950 (Washington. D.C.: Catholic University Press, 1962), 149. 
Perfidious and uncontrollable as it may prove to those who try to master it, epic has a tendency to become fixed and monolithic when viewed over the shoulder. Its definitive heroes are volatile, treacherous, or neurotic (Achilies, Odysseus, Aeneas); from afar, they are often mistaken for patriarchs, much as Apollo and Dionysus snatched from context have been made to serve iconographically for Christ. Inscribed in the canon, translated, and taught in school, its great successes seem sedate.

Indeed, they do lose something in the original: certainty. The "realms of gold" that Keats found in Chapman's Homer may have seemed a splendid monstrosity to a Greek audience used to short heroic lays. As Kirk observes of the monumental poem, "by the normal canons of heroic song this kind of poem is an aberration." ${ }^{44}$ Some singer, either heroically ambitious or assisted by the new technology of writing, was stringing together a week's entertainment from Trojan tales, borrowings from other cycles, catalogues, riotous Götterkomödie, self-parody (Thersites, Nestor), ecphrasis, and a hero, given to tantrums and existential speculation, who actually fights for only four books out of twenty-four. Legions of textual surgeons have not belabored the "Homeric question" for two centuries to cure an excess of uniformity. Virgil wrote by the thousands a neoteric verse form developed to be read by the dozens and, through this massive miniature, refracted his encomium of Rome into myriad congruent and dissonant voices, not so much sung as quoted, overheard, dreamt, meant, and not meant. Beneath the stately and unified diction are a welter of generic influences: Homeric, Alexandrian, and Roman epos; Greek and Roman tragedy and lyric; oratory and decrees. Dante mixed satire, pagan heroics, scripture, lyric, Ovidian metamorphoses, and homilies as he circumnavigated the cosmos in the vernacular and wrote universal history as autobiography. Had they not come to define the tradition, these experiments might rank as travesties.

\section{Polyphony and Pentecost}

Mikhail Bakhtin centers his analysis not on genres but on the opposed generative principles of all literature, the "epic" and the "novelistic." The now

${ }^{44}$ Geoffrey S. Kirk, The Songs of Homer (Cambridge: Cambridge University Press, 1962), 280. See, in general, 271-300. 
defunct "epic" derives from a monoglot culture (Bakhtin cites only Homeric Greece) that can express its central values in a "high and straightforward word without the interplay of voices, ironies, and languages of the "novelistic" as it emerges from periods of linguistic mixture and confrontation. The "novelistic" consolidates itself in the orientalizing ("Hellenistic") mode of Greek culture (after Alexander, third century B.C.E. onward) and in bilingual Rome, then reasserts itself strongly in the linguistic struggle that brought the vernaculars out of Latin in the Renaissance. Interestingly, the polyphonic forms that Bakhtin sees as the telos of literary development are those satiric, personalistic, many-voiced texts that Gogol a century before had described, in his survey of poetry from Lomonosov to Pushkin and Zhukovsky, as being distinctively Russian. The penultimate chapter of his final work, Selected Passages from Correspondence with Friends, entitled "On the Essence of Russian Poetry and on Its Originality," locates quintessential Russianness in polyglossia, the power of language as it is only now being discovered by the Russians themselves:

After all, our extraordinary language is itself a secret. In it are all the tones and all the shades, all the transitional sounds from the solidest to the tenderest and softest; it is unlimited and can, living like life, at every moment be constantly enriched, drawing, on the one hand, from the sublime words of the biblical language of the Church, and, on the other, choosing to select accurate terms from the innumerable dialects scattered through our provinces, thus having the possibility in one and the same speech of ascending to heights inaccessible to any other language and of being lowered to a level of simplicity appreciatively felt by the dullest of men.... ${ }^{45}$

Gogol's history organizes itself around an absence: Russian literature does not have at its center a work to pull the pieces together. "It [poetry] has accumulated only in one pile innumerable little hints of our diverse qualities; it has brought together in one depository various unconnected sides of our many-sided nature" (p.243). The problem for the Russians strikingly parallels the bilingualism that Bakhtin finds generative for the Romans, the incorporation of a more evolved literary language (French,

${ }^{45}$ Nikolai V. Gogol, Selected Passages from Correspondence with Friends, trans. Jesse Zeldin (Nashville. Tenn.: Vanderbilt University Press, 1969), 248. When necessary, we have altered Zeldin's translation to provide more accuracy. 
like Greek) that forces the new literature to proceed with particularly acute self-consciousness - to speak, as it were, always in the mode of quotation.

Gogol is a particularly interesting source because he initiates an epic project that is inimical to Bakhtin's values. His attempt to move the novel toward being authoritative, culturally central, and nationalistic, as in some measure Gogol does, is to Bakhtin a betrayal of what is lively, subversive, and anti-authoritarian in the "novelistic." Bakhtin considers War and Peace monophonic and claims that Gogol "lost Russia" in trying to work the "novelistic" beginning of Dead Souls toward some kind of monumentality.

"Epic" as defined by Bakhtin may prove to be a phenomenon of reception more than a generative principle. As Morson has shown, as a narrative War and Peace responds fruitfully to Bakhtin's theory. ${ }^{46}$ Yet the book has another life, for when it is taught in translation with classroom materials that gloss over its pointed anomalies, this once aberrant and provocative unmaking of the novel stands as an unproblematic and definitive "classic." The now canonical epics themselves came from the very moments of linguistic "interanimation" that Bakhtin emphasizes. Greek lurks behind the Latin of Virgil and Ovid, as does Latin behind Milton's English and Dante's Italian. When Gogol himself, in his retreat to Rome to write the great Russian novel, used Italian to liberate Russian from French, his gesture seemed as much a part of the Virgilian-Dantesque tradition as of "novelistic" tendency. All such works are received as monophonic and authoritarian once they have been flattened by translation, removed from the controversies of their time, and imposed on the young. Even Bakhtin's beloved Rabelais and Dostoevsky experience that dull fate when they become required reading as classics - that is, in Bakhtin's terms, as "epics."

Bakhtin's field theory of literary production so powerfully discredits the pieties and simplifications of literary historians, those purveyors of category and period, that it thwarts even his own attempt to locate "epic" and "novelistic" as historical principles. He skirts the historical paradox of how "novelistic" are the processes by which the cultural center gets constituted in the first place. To take a turning point that is paradoxical in all such histories, his Socrates midwifes "dialogism" as Plato's does philosophy. Yet

${ }^{46}$ Gary Saul Morson, Hidden in Plain View: Narrative and Creative Potentials in War and Peace (Stanford, Calif.: Stanford University Press, 1987). 
a contradiction lurks between these claims: Plato's dialogues may be the prototype of "novelistic" style, as well as of free inquiry, but they scarcely serve the spirit of carnival. To be sure, Kristeva sees Bakhtin's analysis as a corrective to Nietzsche's attack on Socrates as a destroyer of some such tendency (that is, the Dionysian as it anticipates Bakhtin's "carnivalesque"). ${ }^{47}$ Yet, in the larger historical perspective, Nietzsche's critique retains its power. The primordial spirit of Dionysus (or of carnival) has no enemies more potent than the Academy, the transcendencies of Platonism, and, ultimately, Christian theology.

We are left with an ineradicable paradox: the basic pattern of Bakhtin's larger history is contained and reversed already in the distance traversed between Socrates in the marketplace, affirming nothing but the value of questioning, and Plato, who passed down his esoteric doctrines, the absolutes of Platonism, behind the walls of the Academy. A public gadfly inspired the foundation of the Ivory Tower; free inquiry hardened into a party line; the "popular" prose form of the dialogue supported intellectual, political, and, eventually, theological elitism. In a word, the polyphonic gave birth to the monophonic. Part of the codification that simultaneously killed and immortalized Socrates' liberating assault on received wisdom and social convention was Plato's "novelistic" gift (and he has few rivals in prose) of capturing on paper the polyphony of Socrates as he is reported in action.

Bakhtin observes, "Neither an epic nor a tragic hero could ever step out in his own character during a pause in the plot or during an intermission: he has no face for it, no gesture, no language." ${ }^{8}$ In contrast, Socrates presides over a world that has no conventional plot, only intermissions. Here the great players in history, like the Symposium's drunken Alcibiades before the Sicilian expedition, come stumbling in with their masks a-kilter, and the gap between self and society becomes the beginning of wisdom. Yet in making Socrates' life the new plot, the only true plot, Plato created a world incomparably more seamless and uniform, more ranked, centered, and organized than Homer's. Achilles only exemplified the old heroism (and that but fitfully); Socrates was coextensive with the new, the flesh

47 Julia Kristeva, Sēmeiōtikē: recherches pour une sémanalyse, Collection "Tel Quel" (Paris: Editions du Seuil, 1969), 163.

${ }^{48}$ Bakhtin, "Epic and Novel," 36. 
made spirit. Plato's playful, richly voiced prose promoted the very cultural monolith that the "novelistic" dismantles.

Bakhtin's stylistic analyses of seriocomic forms in antiquity remain unsurpassed, but ideologically he nods, and recent scholarship leaves little to support the history that he implies. Popular laughter, daily life, and the open-ended present come into literature with Aristophanes' comedies, as they do in Plato's dialogues, and Aristophanes leaves no doubts: Socrates is no friend of the démos. The comedian does not restrict his characters or his audience to an elite, but Old Comedy is something of a literary dead end. As in the Platonic dialogues, popular laughter is destined to be memorialized mostly in libraries. Another of Bakhtin's central examples, Petronius also promotes popular forms into artistic prose but, as a courtier of Nero, is presumably not expressing the Volksgeist in any simple way. Scholarship since Bakhtin has undermined the impression that the descent of literature into the streets and into the open-ended present might reflect movements of authorship or readership. Apart from the mostly lost farces, the emergent popular forms that Bakhtin favors tend to be regarded now as "probably written as lighter reading for the intelligentsia," as Bowie observes of Lucan and the Greek novelists. ${ }^{49}$ It was the earlier forms like Homeric epic and Attic tragedy, which Bakhtin sees as stifling the popular imagination, that in fact entertained and unified the whole society.

As other cornerstones of Europe as the Culture of the Book, Homer and the Bible are equally involved in the paradoxes of the oral passing into the written, in this case the process of folklore becoming textually fixed and scriptural. ${ }^{50}$ Much of Bakhtin's project can be seen as tracing the recovery

${ }^{49}$ E. L. Bowie, "The Greek Novel," in The Cambridge History of Classical Literature, vol. 1, Greek Literature, ed. P. E. Easterling and B. M. W. Knox (Cambridge: Cambridge University Press, 1985; rpt. 1987), 688.

${ }^{50}$ Bakhtin discusses the influence of the Bible, but not its creation (see "From the History of Novelistic Discourse," 69-71). Writing before this essay was published, Erich Auerbach, in Mimesis, contrasted the externality of Homeric characterization with a more mixed and inward-looking style first exemplified in Genesis. Auerbach's characterization of Homeric style has largely been dismissed by classicists; see, for example, Jasper Griffin, Homer on Life and Death (Oxford: Clarendon Press, 1980; rpt., 1983), 50-80 (earlier critiques cited, p. 70, n. 37). On Bakhtin and Auerbach, see Tzvetan Todorov, Mikhail Bakhtin: The Dialogical Principle, trans. Wlad Godzich, Theory and History of Literature, vol. 13 (Minneapolis: University of Minnesota Press, 1980), 89-90. Originally published as Mikhail Bakhtine: le principe dialogique (Paris: Editions du Seuil, 1981). 
in prose of the "voice" lost as oral forms reduced themselves to the silent page. Just as between Socratic play and Platonic doctrine, we are forced to make other distinctions: between epic as sung and created and Bakhtin's "epic" as received; between the Bible as created and scripture as imposed. Both the Homeric epics and the Hebrew Bible are aggregates of radically heterogeneous material that does not become less complex by being compiled. Even in the Iliad philologists have come to appreciate a quality of multivoicedness in the tension of speeches and narrative. ${ }^{51}$

Palestine and the Greek coast of Asia, Homer's Ionia, are Bakhtin's linguistic crossroads par excellence. ${ }^{52}$ It seems misleading to treat either aggregate, Bible or Homer, as the dead cultural center and the outgrowth of some organized political intention when the "national" identities being asserted are more caused than celebrated by the texts themselves. In antiquity, both Greece (never a nation) and Israel have a firmer identity in these texts than they did on the map. The texts' affirmation of hierarchy often involves irony: what are we to make of the king or patriarch as trickster (Odysseus, Jacob)? The cultural reach and narrative power that render this writ holy are oral, folkloric, quintessentially polyphonic. For Bible, as for epic, the lack of "interiority" is not a safe assumption. ${ }^{53}$ It is the processes of reception - the reduction of performances to inviolable texts, of a lively industry to a few official survivors, and of a colorful Kunstsprache

51 Even three decades ago Hermann Fränkel, a scholar of Auerbach's generation and similarly a proponent of Geistesgeschichte, could describe what in Bakhtin's terms seems to be a dialogical quality in Homer: "The restraint which the epic poet imposes upon himself is set aside in the numerous speeches which he weaves into his work. Only so long as the singer is reporting events does he remain a mere shadow, discreet and neutral... In general the speeches are freer and richer; their style and their mode and course of thought are more modern than is narrative. In the speeches we find quite often ideas, reflections, relationships, in contradiction to those upon which the narrative and action rest. It is as if forces held in check had here broken out with elemental strength." Early Greek Poetry and Philosophy, trans. Moses Hadas and James Willis (New York and London: Harcourt Brace Jovanovich, 1975), 39-40. Originally published as Dichtung und Philosophie des frühen Griechentums (Munich: C. H. Beck'sche Verlagsbuchhandlung, 1962).

52 That it was the very marginality of Ionia which enabled the Homeric definition of "Greekness" is a traditional speculation elegantly formulated by E. M. W. Tillyard, English Epic, 36-39.

${ }^{53}$ Along with Auerbach, see, for example, the readings of Robert Alter, The Art of Biblical Narrative (New York: Basic Books, 1981). 
to flat, pious translationese - that create the impression of simplicity. ${ }^{54}$ The monophony of "epic" may result more from our tone-deafness than from the processes that create the aggregations which then become the anchors of society.

Problematic as is Bakhtin's category of "epic" in historical terms, it does describe a phenomenon central to the traditions we are tracing. For the poets themselves exploit the "epic" sense of authority and centrality by parading their own grand inheritance and celebrating the canon they wish to join. Yet in the very act of pretending that their inheritance is grand and fixed, they distort it freely, as they must, and render the canon malleable. As was discussed above, the statuesque assemblage of Virgil, Homer, Horace, Ovid, and Lucan in Inferno 4 gives only a first and dangerous illusion of the canon, for Virgil's mobility and the encounter with the converted Statius will redeem the very concept of canon from its secular and ancient terms. Harold Bloom finds a similar freedom in Milton's adaptation of epic ecphrasis. Whereas Homer and Virgil miniaturized the world on their heroes' shields, Milton presents Satan's shield as a microcosm of his own literary antecedents, optically distorted (complete with Galileo's glass) to fill his own needs: "Milton does what Bacon hoped to do; Milton and Galileo become ancients, and Homer, Virgil, Ovid, Dante, Tasso, Spencer become belated moderns." 55 At key moments in the epic pilgrimage, the tradition itself steps forward to guide the seeker. Yet the tradition thus embodied may represent a reconceiving of history more radical than Bakhtin's. In the

${ }^{54}$ On the nature of the performances that lie behind the Homeric texts, see Eric A. Havelock, Preface to Plato (Cambridge, Mass.: Harvard University Press, and Oxford: Basil Blackwell, 1963; rpt., New York: Bantam, 1982), 145-64; Joseph Russo and Bennett Simon, "Homeric Psychology and the Oral Epic Tradition," Journal of the History of Ideas 29 (1968): 485-98; and Bennett Simon, Mind and Madness in Ancient Greece: The Classical Roots of Modern Psychology (Ithaca and London: Cornell University Press, 1978), 78-88.

${ }^{55}$ Harold Bloom, A Map of Misreading (New York: Oxford University Press, 1975), 138. Milton's inversion of time may derive from the scene in the Aeneid (8.626-728) where the baffled Aeneas looks on a divine shield summarizing the history of a Rome that has not yet been founded. Leo Bersani, "Against Ulysses," Raritan 8, no. 2 (Fall 1988): 21, observes a similar absorption and reconstitution of canon in Ulysses: "The Joycean intertext rescues Western literature from the deconstructive effects of the intertext itself. The parodistic replays of Homer, Shakespeare, and Flaubert - not to speak of all the authors "quoted" in "Oxen of the Sun" - are neither subversive of nor indifferent to the fact of cultural inheritance; rather, Joyce relocates the items of that inheritance with Ulysses as both their center and belated origin." 
name of theory he may present an improbably one-dimensional Homer, but consider what Dante does to Virgil out of love: Virgilio speaks Italian, after all, and recants part of the Latin verse of Roman Virgil (Inferno 20). He turns out not only to have inspired Statius but to have converted him to Christianity. ${ }^{56}$ The cultural center that epics celebrate keeps shifting, as does the frontier from which they address that center.

If we separate epics as they came to be written from the concept of monophonic "epic," which we are arguing to be largely a result of reception, we find that Bakhtin's use of counter-genre proves useful for describing the dialectic by which the tradition advances. He notes that epics generate parodies and reactions to themselves that then belong to another and "novelistic" form. Our view is that these shorter forms - mock-heroic, pastoral, and didactic poetry - regularly become reabsorbed into the larger syntheses that we are calling epic, which grow all the more "novelistic" thereby. The Iliad and Odyssey incorporate and derive from shorter forms at various levels of seriousness (for example, the Odyssey's Demodocus sings a ribald tale of Aphrodite and Ares at 8.265-366). And archaic epos presents a range of didactic verse (Hesiod), as well as the Homeric Hymns' mixture of humor, etiology, and piety. Between Homer and Virgil lie the countermonumental short, variegated forms of the Alexandrians (Theocritus, Callimachus, Apollonius Rhodius) that are reabsorbed into the larger forms of Virgil and Ovid. Between Virgil and Dante one of the major links is the counter-epic of the insouciant Ovid. ${ }^{57}$ Within this familiar cycle of serious monuments and the reactions thereto, even the most unlikely swings are now well studied, for instance, that between Ovid and the unsmiling Milton. ${ }^{58}$ That successful epics temporarily exhaust the form was a commonplace assumption already in antiquity, and how a great cultural synthesis like the Aeneid should leave Ovid to look elsewhere as he

56 On Dante's restaging of the tradition, see the section "Epic Resolution" in Teodolinda Barolini, Dante's Poets: Textuality and Truth in the Comedy (Princeton, N.J.: Princeton University Press, 1984), 188-296.

57 On Ovid and epic, see Brooks Otis, Ovid as an Epic Poet (Cambridge: Cambridge University Press, 1966; 2nd ed., 1970) and Robert Coleman's review, "Ovid and the AntiEpic,.". Classical Review n.s. 17 (1967): 46-51.

${ }^{58}$ See Louis L. Martz, Poet of Exile: A Study of Milton's Poetry (New Haven and London: Yale University Press, 1980), and Richard J. DuRocher, Milton and Ovid (Ithaca and London: Cornell University Press, 1985), who usefully survey work on countergenre. 
constructed his fifteen books of universal history in ironic and metamorphic terms needs no further explanation.

These ironic forms are not just a medium for epic concerns to reformulate themselves between monumental syntheses - the valleys between the peaks, as it were - but are often the mode in which an opening can be made by epics or by novels in the epic tradition. Though mock heroic was the path taken by Sterne and Fielding to work forward from epic poetry to the novel, Joyce was scarcely the first to demonstrate that the same path also leads backward; we shall be arguing that case for Gogol. ${ }^{59}$ The larger epic journey, as mapped by Dante and then Milton, begins infernally: with descent, mockery, and derision - that is, with the central mockheroic operations of seeing the great ones of this world frozen, shrunk, and humiliated. Even the Iliad begins, not with battle, but with heroes throwing tantrums. Heroism manifests itself faster and more interestingly by its deformations than by its triumphs, which, narratively, must always be rare and climactic. Indeed, it has never been supposedly useful, dignified triumph that fixes the paramount heroes in the mind but, rather, peculiar scenes like Achilles' mutilation of Hector's corpse, Odysseus' being beaten as a beggar, Heracles' killing of his wife and sons. The normative hero being normatively heroic can radiate glory from a temple frieze or metope but plays no more than a supporting role in epic (see Homer's Diomedes, Ajax, Patroclus, Sarpedon): there is just no story in it. The heroism that is the simple, static, ancient thing from which literary theory traces all the interesting variations and debunkings turns out to be more like the severe and focused idealism of classical sculpture, which Hegel and Nietzsche found a more manageable inspiration than the disruptive heroes of Greek poetry. In epic, a heroic figure can include all manner of contradictions indeed must include them - as long as they are explosive contradictions. It is scarcely out of the question for Gogol in Dead Souls to start with infernal descent and conceive that it might be leading somewhere higher.

The serious shorter forms also figure in the epic tradition, indeed shape the canonical epic career as, following Virgil's pattern, it progressed from

${ }^{59}$ For an astute appreciation of the interplay of the high and low mimetic modes in heroic literature, see George deForest Lord, Heroic Mockery: Variations on Epic Themes from Homer to Joyce (Newark, Del.: University of Delaware Press, 1977). 
pastorals (the stylus humilis) to georgics (the stylus mediocris) and finally to the Aeneid (the stylus gravis) - a course followed in various ways by Dante, Ariosto, Milton, and Pope. We noted above that epic, though by appearance the most encompassing and self-sufficient of forms, is uniquely dependent on the texts that precede it - that is, can speak only as the end and consummation of some much longer discourse over the centuries. A second paradox now emerges about epic as a uniquely contingent form: apart from the Iliad, epics have credibility only as they come at the end of certain kinds of careers. Even the Odyssey was explained by PseudoLonginus as the product of Homer's old age. In prose, apprenticeships that advance from short to long, humilis to gravis, are regular: from short story to novel in Tolstoy's case and from Joyce's Dubliners to A Portrait of the Artist to Ulysses. We shall argue much the same for the progression from Gogol's short stories to "Taras Bulba" to Dead Souls. The larger form can be seen to incorporate and comment on the shorter forms. ${ }^{60}$ With autobiographical or semiautobiographical narratives, the career then becomes the pilgrimage (Dante's Comedy). Far from becoming juvenilia, these shorter early texts have continuing use in any oeuvre because they explain things about the culminating masterpiece - the Aeneid or Paradise Lost - that the text cannot explain about itself. For these minor forms, like the pastoral and the georgic, do not so much memorialize some closed heroic age as mediate between past and present, the grand and the everyday, the heroic and the political. Hence it is that readers can find the "true" Virgil in the less encumbered voice of the Georgics or the Eclogues, and more Milton in "Lycidas" than in Paradise Lost. The great epics thus do not speak to their age in isolation but in fact rely on these "satellite" forms as a kind of buffer, a mode of translating heroic values to ordinary use in ways that go beyond what the epics themselves can provide. Gogol's placement of "Taras Bulba" within the Mirgorod cycle will provide a concrete example of this need to cushion and insulate the boldest heroic statements.

${ }^{60}$ Ralph Cohen argues that the basis of genres in the eighteenth century was a hierarchy in which the lower forms tended to inclusion in the higher (for example, epigram into satire, sonnet into drama). As the highest form, epic was the most inclusive. See "On the Interrelations of Eighteenth-Century Literary Forms," in New Approaches to Eighteenth-Century Literature, ed. Phillip Harth (New York and London: Columbia University Press, 1974), 33-78. 
As with the created memory of "heroic ages," the simplicities imposed on epics - noble to Lukács, dull to Bakhtin - are themselves an important element in the tradition, for they suggest the field of reader expectations in which writers of epic operate or which they share. Bakhtin's brief analysis of Dead Souls reflects precisely the misapprehensions of epic that may have led Gogol himself astray: "The form of his epic Gogol modeled on the Divine Comedy; it was in this form that he imagined the greatness of his work lay. But what in fact emerged was Menippean satire. Once having entered the zone of familiar contact he was unable to leave it, and he was unable to transfer into this sphere distanced and positive images" ("Epic and Novel," p. 28). Bakhtin sees in Menippean satire, mixing as it does prose and poetry, high style and low subjects, an ancient precursor of the novel, a form that stands in familiar, disrespectful proximity to its subjects. What he excludes is that "the zone of familiar contact," the satirist's underworld, could be the traditional starting place of cosmic journeys. Yet may it not be the attempt to leave this fallen world that distinguishes the bard from the satirist, regardless of whether or not that attempt is successful? Dante's escape is acknowledged; Milton's remains controversial (did Satan win?); Gogol burned his sequel and turned to epistles. Bakhtin continues: "Gogol could not manage the move from Hell to Purgatory and then to Paradise with the same people and in the same work; no continuous transition was possible" (p. 28). Yet what Bakhtin expects of Purgatory, as of the whole epic landscape, is the stuff not of epic but of scripture (and of theology more than of scripture). His confusion is interesting, for it may replicate the literalism that left Gogol himself forever waiting at the gate: "It [the epic world of the absolute past] is given solely as tradition, sacred and sacrosanct, evaluated in the same way by all and demanding a pious attitude toward itself" (p. 16). But, of course, Dante's mundanely angelic Purgatory proves accessible precisely because it is such an ambiguous realm, so complexly human. It is not the world of the absolute past or the coming eternity, but proceeds, as do we, under the cycles of the sun. There is no angel at the gate, but Roman Cato; pagan history, myths, and art are not left behind but continue on, tellingly juxtaposed with biblical. Pagan Virgil is finally abandoned, but not before Roman Statius has joined up. The transitional nature of this realm is emphasized stylistically by the degree to which the style is scriptural and non-scriptural, or rather half-scriptural and entirely epic. To the large degree that Purgatory is the invention of Dante's 
own imagination rather than of Christian theology, it bears its own selfqualifications as metaphor and is not "given solely as tradition." Indeed, the farther Dante gets from Hell, the less tradition he has to go on. Purgatory is a poetic realm characterized by all the complicated give-and-take with contemporary reality - of spirit into flesh - that Bakhtin excludes for the epic and that Gogol himself may never have grasped as appropriate for the redemptive mode of his commedia. Hardest of all to portray is a second birth that is a rebirth into flesh, a promotion to humility: "Gogol lost Russia, that is, he lost his blueprint for perceiving and representing her; he got muddled somewhere between memory and familiar contact - to put it bluntly, he could not find the proper focus on his binoculars" (p. 281). To be sure, there is a muddle between the grubby particulars of Gogol's provincial $\mathrm{N}$ - and the vast shadow cast by a once and future Rus', but can we be sure that it is not a designed muddle? - that the blurring shift of focus, the near suddenly seen from afar, is not one of the characteristic effects of epic?

In Selected Passages Gogol, like Bakhtin, is a theorist trying to explain why the narrative of Dead Souls stalled after the first installment. As noted above, his history of Russian poetry centers on a notion of heteroglossia very like Bakhtin's, and equally teleological. The penultimate chapter of Selected Passages, on the originality of Russian verse, is Gogol's literary posing of the question Whither Rus'? Yet Gogol reverses Bakhtin's direction almost exactly. The lack of a monumental center is not a liberation but a captivity. Having surrendered to the French language and European writers, the Russians do not yet know their own language. It remains hidden, fractured, unresolved:

Our poets have perceived that the time has not yet come to paint us as a whole and brag about us, that we must still be organized, become ourselves and make ourselves Russians. Our nature is still too soft, still too unprepared to take the form fitting to it; we have still not had time to take in the total of that multitude of elements of all kinds and all origins brought into our land from every place, an incoherent concurrence of alien forces within us, an unwise result of a concatenation commanded by God. (Selected Passages, p. 243)

The inchoate diffuseness of Russian culture is a form of Babel, and Gogol moves to the final chapter, "Easter Sunday," with a vision of the descent of the Holy Spirit that recalls the reversing of Babel at Pentecost: 
This [true Russian] speech will pass into every soul, it will not fall on sterile soil. Our poetry will be imbued with an angelic passion and, having struck every string there is in the Russian, it will move the most hardened soul with a holiness with which no power and no instrument in man can contend: it will evoke our Russia for us - our Russian Russia. (p. 248)

Gogol's vision is radically centripetal. It looks, like Pentecost, to the rescinding of difference, to unification. Here we see clearly the Gogol who had left himself no human language with which to work. He was possessed of a theory whose absolute terms prevented him from speaking at the cultural center - that is, from giving Russia the monument she wanted by the assumption that such a center must be unitary, fixed, not just stable but eternal, not entirely of this earth. His radical insistence on throwing off foreign masters leaves him with no access to the international tradition that established Greek epic at the Virgilian center of Roman letters, pagan Virgil as Dante's guide to the Christian afterlife, and Catholic, Italian Dante himself as guide to Chichikov's pilgrimage through the dead as it gave birth to the Russian novel.

\section{Temporal Closure}

If the epic tradition cannot be firmly fixed within an "epic age," it may still confine itself to describing some such thing. The handling of time has been invoked since Goethe ${ }^{61}$ to differentiate epic from other forms - tragedy for Goethe, the novel for Bakhtin. ${ }^{62}$ Epic is said to assume a fully distanced, completed, irrefutably glorious age that is "vollkommen vergangen," an

${ }^{61}$ In Goethe's 1797 essay (published in 1827 and cosigned by Schiller) “Über epische und dramatische Dichtung," in Goethes Werke, ed. Erich Trunz, Hamburger Ausgabe in 14 Bänden, vol. 12 (12th ed., 1981), 249-51.

${ }^{62}$ Goethe locates the distinction in the different modes of performing, not writing, epic and tragedy, that is, between the rhapsode's impersonal narration of past events and the mime's reenactment. Later work on oral poetry has largely discredited this distinction (see above, nn. 50 and 54). More than half of both the Iliad and the Odyssey consists of highly performable speeches.

In his critique of Bakhtin's failure ever to define or limit the category of "novel," Todorov (Mikhail Bakhtin, 89-90) discusses this transformation of Goethe's antithesis and notes that Plato would class both epic and novel as diēgēsis, as Bakhtin himself tends to do in his later writings. 
"absolute past." The values of this age are fixed and normative and are not subject to reinterpretation by the anonymous bards who celebrate them. There are, indeed, ancient epics (the Iliad) and modern imitations (Gogol's "Taras Bulba") that maintain this distance; but apart from Homer they are rare even in antiquity. The interweaving of the ages of Aeneas and Augustus in the Aeneid typifies the etiological mode of epos that may have been dominant even before the Iliad. ${ }^{63}$ As on other counts, then, the simplicities of the "epic" pole may be delusory.

The forms that replace the epic - tragedy, the novel, and arguably film - deal with the indeterminacy of the present, the "vollkommen gegenwärtig," and the ineluctable subjectivity of perceiving that present as well as of generating values for an everyday world that has not, as in epic, been fossilized into gloire. In Bakhtin's formulation, the open-endedness of the novel as a form responds to the open-endedness of history as we experience it. Now, the drift from the one mode to the other does encapsulate much of literary history in the period when the novel has been attaining predominance. Modern literature manifestly concerns itself with contemporary and ordinary things, "low" subjects, to a degree that ancient did not. Yet within both the epic tradition and the novelistic mode we find works that mix these two temporal perspectives and distinguish themselves in important ways along this same axis. Therein lies much of how the Odyssey as a sequel sets itself apart from the Iliad, for it shifts the focus from battle to marriage and housekeeping, slaves and peasants, the foolishness of taking risks and the glories of one's own backyard. To be sure, the events recounted officially belong to an age as distant and closed as that of the Iliad, yet nothing delineates Ithaca as lost or unattainable in quite the way that Troy is. Conversely, some historical novels, like those of Sir Walter Scott, present a kind of temporal closure, an "absolute past," in contrast to the contemporaneity and subjectivity of Ulysses, where the pervasive evocation of Homer serves not to distance and separate past and present but to entangle them in poignant confusion. Certain subjects too lowly for the bourgeois sensibilities of the novel can be accommodated precisely to the extent that the novelist aspires to the "high" form of the epic, with its greater interest in myth and fantasy. For it is as part of an

63 This possibility has been explored most fully by Gregory Nagy, The Best of the Achaeans (Baltimore and London: The Johns Hopkins University Press, 1979; rpt., 1981). 
enchanted landscape, an escape from urban, middle-class conventionality, that Tolstoy's wise peasants, Platon (Plato) Karataev in War and Peace and Platon Fokanich in Anna Karenina, emerge to prophesy and redeem, as descendents commonly of Christ as shepherd and the wise Odyssean herdsman, Eumaeus.

In their fullest forms, epics and novels combine both senses of time, and it may not be the proportions that qualify any given work as epic or novelistic, but rather the direction charted between past and present. That is, it is not the lack of connection with the current time that characterizes the epic so much as the appropriation of contemporary realities to create an importance like that of the past, a raid conducted on the present by a grander past. Writers may permit themselves surprising turns on this issue or, to use Bakhtin's image, refocus their binoculars. Dante's first audience might well have been surprised to find something as immemorial as Hades filled with Florentines whom they may have known personally. His larger intention was not to bring great traditional ideas like Heaven and Hell down to the level of daily reality but, on the contrary, ultimately to claim that near and credible reality for the larger eschatological perspective. We must be alert to the possibility that Gogol did not just betray epic in order to look satirically at contemporary Russia but ended up by claiming the satirized countryside for the eternal notion of Rus'.

In respect to the sense of time, one can find this doubleness in all epics after Homer as a result of the double plot discussed above. Even when the action transpires in some decisively closed age, the allusiveness of the language, the degree to which it renews rather than remembers what has been said before (or rather how it has been said), contradicts the whole notion of closure. Writing as he does, Virgil is a more material reincarnation of Homer than Augustus is of Aeneas, for words can be preserved and reused in a way that power cannot. In all Christian epic, even when the argument declares pagan antiquity to be a closed chapter, that past culture lives on as a generative principle in the style. The notion of the Epic Muse baffles the modern imagination in instructive ways. Does she symbolize the weighty authority of received tradition, the certification of accurate memory, or, on the contrary, some liberating access of inspiration? Does she serve ars or ingenium? Are her gifts agelessly fresh or long fossilized? Faced with these contradictions the epic poet addresses the fixity of the past in a constantly transmuting poetic medium that itself eludes fixity and 
even (in the Grecizing Latin of Roman epic, the Latinate Italian of Dante, and un-Englished English of Milton) the separate identity of particular languages. Though the novel may be the fruit of a polyglot era, as Bakhtin observes, it can and usually does speak in a single language in a way that fully realized epic cannot. Quite unlike its plot in illo tempore (when such it is), the language of epic is all history and no past - or rather, a past not remembered but spoken. As is the nature of prose, the language of the novel ages far more quickly and conspicuously than the atemporal artificialities of epic discourse. In incorporating epic tones, obsolete as the theorist may find them, the novel does not become instantly antiquated in its discourse so much as it strives to agelessness and insulation from its own passing moment. In other words, anachronism may be an active defense against obsolescence.

Novels, like all modern literature, explore subjectivity more intensively than does ancient poetry. Yet one cannot therefore claim that the movement toward subjectivity is necessarily a movement away from epic, for in the Christian system the mind as a place unto itself becomes the true and only site of heroic endeavor, and therefore a fit ground for epic struggles. Confessional literature, starting with Augustine, provides one of the purest embodiments of novelistic tendency. Dante turned it into epic; and no one will claim that he is deficiently confessional or, in Christian terms, deficiently heroic. To deal with this problem, Lukács sees Dante as moving backward and forward simultaneously, for in him "principles of structuration which tend toward the novel are re-transformed back into the epic." ${ }^{64}$ As noted above, epic may identify itself in contradistinction to the novel not by the proportions of its temporal and evaluative perspectives, but by the movement among them; not, that is, the net amounts of "high" and "low," "far" and "near," "then" and "now," but by a final redemptive drift (even if it seems only a blurring of focus) that snatches up humbler things to serve higher perspectives, even if those higher views are just questions and muddled hopes.

${ }^{64}$ Lukács, Theory of the Novel, 82. John Freccero uses Lukács's observations as the basis for a reading of Inferno 26. See "Dante's Ulysses: From Epic to Novel," in Concepts of the Hero in the Middle Ages and the Renaissance, ed. Norman T Burns and Christopher J. Reagan (Albany: SUNY Press, 1975) 101-19; reprinted in John Freccero, Dante: The Poetics of Conversion, ed. and intro. Rachel Jacoff (Cambridge, Mass.: Harvard University Press. 1986), 136-51. 
In adopting this perspective, we shall perhaps be less baffled that the most monumental of novelistic traditions - and by including works like War and Peace, The Brothers Karamazov, The Quiet Don, and The First Circle we can reasonably call it the most epic - should take its beginning from Chichikov's visit to a village of living dead and immense pygmies. For, as we have noted, it is not unprecedented in the epic tradition, or at least around it, for smaller to give birth to larger and mockery to spawn high seriousness, that is, for heterogeneous and "low" materials to coalesce into a larger hope. As we shall see, in some ways this is the argument of Dead Souls itself. In presenting epic more as cycle than as genre, as a mode of other genres rather than a form unto itself, we propose a new meaning to the familiar designation of an "epic tradition" in the Russian novel. For it is not just scale and calling that define the category but the quality of memory that attaches the novels to the prophets of other nations - Homer, Virgil, Dante - and novelist to novelist, as in Dostoevsky's implicit sense that he is not just replicating or rivaling Gogol's vision but materially continuing his project, as we shall see. This is a quality of memory potent enough to transform the view even of proximate, ignoble reality.

As we noted at the outset, using the great bards entails some hidden costs. Once one has invoked Greeks, Romans, and Florentines to drive French books from Russian soil, one may find oneself still culturally enslaved to equally foreign and merely older masters. They may allow the writer to speak for the very origins of civilization, now pristinely recreating themselves on Russian soil, and may validate his prophetic tone. Yet such necromancy is easier to start than to stop, and what may be reexperienced are not just the primal virtues and vigors of Western culture but its first schisms - schisms that call into question the very act of making fictions and other false idols. The conqueror of Parnassus may regret that it was not Zion. Beyond the bards one finds the prophets; behind epic, scripture; behind heroes, patriarchs. The antique perspectives that adroitly celebrate Russian spirituality in contrast to European materialism also evoke the secular, pagan origins of epic. Though more uncontaminated than the current moment, antiquity itself proves to have its better and worse parts.

The journey beyond novelistic fiction may then continue on beyond any fiction whatsoever, as we see in the careers of Tolstoy and Solzhenitsyn in the wake of Gogol, to whom we now turn. Viewed over the shoulder, epic 
becomes scripture, and this, with surprising frequency, turns out to be what the epic novelists of Russia finally decide that they want to write or to have written. Yet the force and richness of the tradition is also such that the same men as theorists, Russians, or Christians may discuss epic as one thing but write it as quite another, aspire to it as monolith but execute it, necessarily, as mosaic. 